San Jose State University

SJSU ScholarWorks

Faculty Publications, Chemistry

Chemistry

$1-1-2007$

\title{
Hydrophobic, Organically-Modified Silica Gels Enhance the Structure of Encapsulated Apomyoglobin
}

\author{
Daryl K. Eggers
}

San Jose State University, daryl.eggers@sjsu.edu

\section{A. Rocha}

San Jose State University

Follow this and additional works at: https://scholarworks.sjsu.edu/chem_pub

Part of the Biochemistry Commons, and the Other Chemistry Commons

\section{Recommended Citation}

Daryl K. Eggers and V. A. Rocha. "Hydrophobic, Organically-Modified Silica Gels Enhance the Structure of Encapsulated Apomyoglobin" Chemical Communications (2007): 1266-1268. https://doi.org/10.1039/ B617078A

This Article is brought to you for free and open access by the Chemistry at SJSU ScholarWorks. It has been accepted for inclusion in Faculty Publications, Chemistry by an authorized administrator of SJSU ScholarWorks. For more information, please contact scholarworks@sjsu.edu. 


\section{RE: Website Email: Re-posting Materials in SJSU Institutional Repository}

2 messages

CHEMCOMM (shared) <CHEMCOMM@rsc.org>

Fri, May 24, 2013 at 5:50 AM

To: "Maribel S. Ramirez" <Scholarworks@sjsu.edu>

Dear Maribel,

Thank you for your email and apologies for the delay in my reply, I had to check with our Contracts \& Copyrights department.

I have been told;

" We do not allow authors to deposit the final PDF of their article in their institutional repository. As this paper was published in 2007 they can deposit the paper now.

Please advise that all SJSU authors can deposit the accepted versions of their papers subject to 12 month embargo from the date of acceptance.

The papers need to be fully acknowledged and link included back to the article on our website."

If you require more information then please do let me know and I will get back to them again.

With Thanks,

Jenny Abbott

Publishing Assistant, Editorial Production

Royal Society of Chemistry, Thomas Graham House

Science Park, Milton Road, Cambridge, CB4 OWF

----Original Message----

From: Maribel S. Ramirez [mailto:Scholarworks@sjsu.edu]

Sent: 23 May 2013 23:26

To: CHEMCOMM (shared)

Subject: Website Email: Re-posting Materials in SJSU Institutional Repository

To: ChemComm Editorial Office

This Email was sent from the following rsc.org page:

/publishing/journals/cc/chemcommteam.asp (http://www.rsc.org/AboutUs/EmailPage.asp?address= nspxnzxxK\%7D\%7En9z\%7Dr\&CCaddress=\&name=ChemComm Editorial Office \&url=/publishing/journals/cc/ chemcommteam.asp)

Dear Editor,

I am contacting you on behalf of Professor Daryl Eggers who is a contributing author to your journal.

Professor Eggers is a member of the faculty here at San Jose State University and would like to deposit the full text of the following article from Chemical Communications in the University's institutional repository. Professor 
Eggers has authorized me to contact you to seek permission to do this on his behalf.

Rocha, V.A., and D.K. Eggers: Hydrophobic, organically-modified silica gels enhance the structure of encapsulated apomyoglobin. ChemComm, 1266-1268 (2007).

The institutional repository is a not-for-profit service for our academic authors, providing access to the full-text of their publications. Full bibliographic details are given for each article, including the journal of original publication.

If possible, it is preferred to archive the finalized PDF version as it appears in print. Archiving the published version has an advantage over mounting the author's own version in that the article maintains consistency in appearance wherever it is read. This also maintains a closer association of the article with the Journal through the header-title and journal house-style.

I would be grateful if you could contact me to give your permission to include this article in SJSU's institutional repository and pass on any conditions associated with the article's inclusion. Please confirm if it would be possible to use the published PDF version of the article for this purpose.

If it is not possible to use the published PDF version, may I include the author's own version in the repository?

In the future if we need to contact you for additional permissions for SJSU-affiliated authors would there be any way to expedite the process or acquire a blanket permission statement allowing SJSU-affiliated authors publishing in your journal to post their works to the institutional repository?

Thank you for your attention to this matter. I look forward to hearing from you.

-Maribel S. Ramirez

SJSU ScholarWorks Staff

Membership No. :

DISCLAIMER:

This communication (including any attachments) is intended for the use of the addressee only and may contain confidential, privileged or copyright material. It may not be relied upon or disclosed to any other person without the consent of the RSC. If you have received it in error, please contact us immediately. Any advice given by the RSC has been carefully formulated but is necessarily based on the information available, and the RSC cannot be held responsible for accuracy or completeness. In this respect, the RSC owes no duty of care and shall not be liable for any resulting damage or loss. The RSC acknowledges that a disclaimer cannot restrict liability at law for personal injury or death arising through a finding of negligence. The RSC does not warrant that its emails or attachments are Virus-free: Please rely on your own screening. The Royal Society of Chemistry is a charity, registered in England and Wales, number 207890 - Registered office: Thomas Graham House, Science Park, Milton Road, Cambridge CB4 OWF

SJSU ScholarWorks Mailbox <scholarworks@sjsu.edu> To: "CHEMCOMM (shared)" <CHEMCOMM@rsc.org>

Thank you very much.

Maribel

[Quoted text hidden] 